\title{
Değişim ve Yenilik Sürecine İlişkin Öğretmen Görüşlerinin İncelenmesi: Nitel Bir Çalışma
}

\author{
DOI: $10.26466 /$ opus.644725
}

\author{
$*$ \\ Esra Töre $^{*}$ \\ * Dr. Öğr.Üyesi, İstanbul Sabahattin Zaim Üniversitesi, Eğitim Fakültesi, İstanbul / Türkiye \\ E-Posta: esra.tore@izu.edu.tr \\ ORCID: 0000-0001-9133-6578
}

Öz

Bu çalışmanın amacı, değişim ve yenilik sürecine ilişkin öğretmen görüşlerini incelemektir. Araştırma, nitel durum çalışması desenine göre yapılandırılmış olup, veriler araştırmacı tarafından geliştirilen yarı yapılandırılmış görüşme formu aracılığılla toplanmıştır. Araştırmanın çalışma grubu, ilk ve ortaokullarda çalışmakta olan 6 farklı branştan 8 öğretmenden oluşmaktadır. Katılımcılara yarı yapılandırılmış 7 adet soru yüz yüze yöneltilmiştir. Görüşmeler sonucunda elde edilen veriler, içerik analizi yöntemi ile analiz edilerek temalar ve alt temalar elde edilmiştir. Araştırma sonucunda, öğretmenlerin "fayda să̆layan, amaca hizmet eden ve kullanulabilir olan" yeniliklere değer verdikleri; "teknoloji", "uyum sağlama", "günceli takip", "kendini geliştirme" temalarım vurguladıkları bulunmuş̧tur. Öğretmenler yenilik ve değişim süreçlerinden, yüz yüze iletişim ile meslektaşlarından, ilgili web sayfalarından, eğitimle ilgili sitelerden ve sosyal medya araçlarından haberdar oldukların ve yine bu yollarla bireysel öğrenmelerini destekledikleri belirtmişleridir. Öğretmenler bireysel öğrenme çabaların destekleyecek araçları, etkili hizmetiçi eğitimler, yenilikleri destekleyecek genel sistem, yenilikleri uygulayacak öğretmen ve yenilikleri uygulayabilecek öğrenme ortamları olarak belirtmişlerdir. Araş̧ırma bulgularından yola çıkılarak; değişikler ve yenilikler öncesi öğretmenlerin konu hakkında bilgilendirilmesi; yenilik sürecine uyum sağlayamayan öğretmenler başta olmak üzere tüm öğretmenlerin bu süreçte desteklenmesi ve denetlenmesi önerilmektedir. İlkyardım eğitimi, yangın eğitimi, yeni öğretim metotlarının kullanımı gibi uygulamalı hizmetiçi eğitimlerin arttırlmasının; okullarda sistemli meslektaş öğrenmesi ve paylaşım çalışmalarının yapılmasının değişim ve yenilik sürecini destekleyeceği düşünülmektedir.

Anahtar Kelimeler: Değişim, Yenilik, Öğretmen görüşleri. 


\title{
Investigation of Teacher Views on Change and Innovation Process: A Qualitative Study
}

\begin{abstract}
In this study, it is aimed to o examine the views of teachers about the process of change and innovation. The research was structured according to the qualitative design and the data were collected through a semi-structured interview form developed by the researcher. The study group consists of eight teachers from 6 different branches working in primary and secondary schools. Seven semi-structured questions were asked face to face. The data obtained from the interviews were analyzed by content analysis method and themes and sub-themes were obtained. As a result of the research, it was found that teachers value innovations that "benefit, serve to goal and useful"; they stated themes are "technology", "adaptation", "current follow-up", "self-development". The teachers stated that they are aware of innovation and change processes, face-to-face communication with their colleagues, related web pages, educational sites and social media tools and they support individual learning in these ways. Teachers cite the tools to support individual learning efforts as effective in-service trainings, general system to support innovations, teachers to implement innovations and learning environments to implement innovations. Based on the research findings it is suggested that informing teachers about changes and innovations; all teachers, especially those who cannot adapt to the innovation process, should be supported and supervised in this process. Increasing practical in-service trainings such as first aid training, fire training, and the use of new teaching methods, systematic peer learning and sharing activities in schools will support the process of change and innovation.
\end{abstract}

Keywords: Change, Innovation, Teacher views. 


\section{Giriş}

Eğitim, tüm toplumlarca en çok önem verilen öğeler arasındadır. Giderek artan şekilde uluslararası söylem, okul gelişimine ilişkin öğretmen çalışmalarının kalitesi ile eğitim reformları arasındaki ilişkiye odaklanmaktadır (Frost, 2012). Eğitimdeki kalitenin artırılması nitelikli öğretmenler ile mümkündür. Yirmi birinci yüzyılda hızla gelişen ve farklılaşan koşullar, öğretmenlerin eğitim fakültelerinde nitelikli bir biçimde yetiştirilmesinin yanı sıra; süreç içerisinde deneyim, bilgi ve becerilerini de geliştirmelerini gerektirmiştir (Gökulu, 2017).

Çağımızda teknoloji başta olmak üzere tüm gelişim ve değişimlerin gerektirdiği beceri, yetkinlik ve bilgi düzeyleri yükseldikçe; eğitimin geleneksel yöntemlerle ve belirli sürelerle sınırlandırılması imkansız hale gelmektedir (Can, 2004, s.104). Bireyin sürekli olarak bu değişimlere kendini uyarlaması, değişen veya yenilenen eğitim koşullara uyum sağlaması için, yaşamını eğitim süreci içinde geçirmesi beklenmektedir (Artan, 1995). Eğitim teknolojilerini iyi kullanma, kendi uzmanlık alanına hâkim olma, öğretim program ve yöntemlerini sorgulayarak mevcut sınıf ortamına göre yeniden tasarlayabilme, sürekli öğrenen kişiler olma bilgi toplumu öğretmenlerinin en temel özellikleri arasındadır (Genç, 2000, s.383-384). Kendi geliştirilebilir alanlarını farkeden, gelişimi keyfi değil olağan ve zorunlu bir süreç olarak algılayan, "yaşam boyu öğrenme ve gelişme" felsefesine sahip öğretmenler etkili öğretmen olarak tanımlanmaktadır (Can, 2004, s.115). Bireysel öğrenme çabası yoğun olan öğretmenler, her şeyi bilen ve bildiklerini eksiksiz aktaran anlayış içerisinde değildirler. Öğrenme çabası yoğun olan öğretmenler, bilgi edinimini sürekli gerçekleştiren, bilgiyi paylaşan ve karşıdakinde bilgiyi paylaşma isteği uyandıran, eksikliklerini tamamlama yollarını arayan bireyler olarak, yeni uygulamalara ve değişime kapı aralayabilirler.

Dewey "Hareket nasıl fiziksel bir gerçekse, değişim de toplumsal bir gerçektir" der (Beycioğlu, Aslan, 2010, s.153). Değişim belli sistematiği dahilinde belli bir sürede herhangi bir şeyde meydana gelen farklılaşmadır (Erdoğan, 2002, ss.8-11). Başaran'a (1998, s.128) göre değişim bir bütünün öğelerinde, öğelerin birbiriyle ilişkilerinde, öncekine göre nicelik ve nitelikte gözlenebilir bir ayrılığın oluşmasıdır. Bu farklılık olumlu ya da olumsuz olabilir. Eğitim sürecinde değişim, öğretmenlerin öğrenme materyallerine ve yöntemlerine ilişkin temel inanç ve fikirlerini yeniden yapılandırmayı 
içerir. (Fullan, 1991). Günlük yaşamda dijital araç gereçler ile çevrelenmiş yeni nesil, yeni teknolojilerle ilişkide yüksek beceri düzeyine sahiptir. Eğitimin içerisinde aktif olarak çalışamaya devam eden pek çok öğretmen ise analog dünyada büyümüştür (Tapscott, 2008). Öğretmenlerin dijital okuryazarlık becerisini geliştirmesi ve bu durumu eğitim-öğretim metotlarına aktarması gerekmektedir ( Turcsányi-Szabó, 2012, s.115). Ancak, zorlayıc1 bir süreç olan değişim duygusal mücadeleyi beraberinde getirir (Tobin, Briscoe ve Holman, 1991).

Değişim süreci eğitim örgütlerini kökten etkilemektedir. Eğitim örgütleri de dğer örgütler gibi değişimi görmezden gelerek ya da değişime direnç göstererek ayakta kalamaz. Bu yüzden örgütlerin değişim gereksinimlerini en uygun seviyede gerçekleştirmesi beklenir (Özdemir, 2000, s.55). Değişim sürecinde öğretmen önemlidir. Seferoğlu (2004) iyi bir öğretmeni "kendisini mesleki ve kişisel açılardan sürekli geliştiren, kendisini geliştirmeye yönelik fırsatları ve olanakları araştıran ve değerlendiren öğretmen" olarak tanımlamaktadır. Öğretmenlerin karşı çıktığı veya istemediği bir değişimi yürürlüğe koymak okul yönetimini zorlar. Öğretmenlerin değişimi benimsemesi için öğretmenlerin amaçları ile değişimin amaçlarının örtüşmesi önemlidir. Bu nedenle değişim sürecinin en başından itibaren, öğretmenleri sürece dahil etmek, her aşamada onların fikrini almak gerekir (Balcı, 1993, s.56).

Değişim süreci sonucunda nasıl bir durumla karşılaşılacağının bilinmemesi, değişimin en önemli özellikleri arasında yer almaktadır (Özkalp ve Kırel 1996, s.413). Öğretmenlerin, değişimin kendilerini nasıl etkileyeceği; uygulamada başarılı olup olamayacaklarına dair endişelerinin olması beklenen bir durumdur (Briscoe ve Peters, 1997, s.52).

Alanyazına bakıldığında değişim ve yenilik kavramlarının pek çok araştırmacı tarafından bir arada kullanıldığı görülmektedir. Altrichter'e göre (2000, s.2) değişim ya da yenileşme, bir ilerleme sürecini ve bu sürecin çıtılarını anlatır. Özdemir'e göre (2000, s.31) ise yenilik, önceden planlanmış olan, kontrol altına alınarak olumlu sonuçlar doğurması planlanan belirli bir değişmedir. Yenilik, pozitif yönde bir değişimi tanımlar. Bir düzeyden farklı bir düzeye geçişin planlanarak kontrollü hale getirilmesi ve verimliliğe dönüştürülmesi; elde edilecek çıktıların beklenençıktılar ile örtüşmesidir. Örgütsel değişimin alt boyutu olarak yenilik süreci, örgütlerin değişen dış çevreye uyum sağlamasını sağlar. Örgütsel yönetimin ana işlevlerinden 
biri, kurumun günlük rutin işlerinin içine yeni fikirleri dâhil etmektir (Köhler vd, 2010).

Yenilik ilk defa Joseph Schumpeter tarafından (1934, s.66) "kalkınmanın itici gücü" olarak tanımlanmıştır. Yenilik ortaya sürülen yeni fikirlerin ürün, süreç, hizmet ve iş uygulamalarına dönüştürülmesi; bunların başarı ile kullanılmasıdır (Banburry ve Mitchgell, 1995, s.163). Musluoğlu (2008) eğitimde yeniliği, eğitimin kalitesini arttırmak, günceli yakalayan ve yaratıcı düşünebilen bireyler yetiştirmek, eğitim sürecini daha etkili, verimli ve hedef odaklı hale getirmek olarak tanımlamaktadır. Gelişen teknoloji, farklılaşan ihtiyaçlarve bu ihtiyaçlar doğrultusunda rolü değişen yeni öğretmeni yetiştirme süreci de eğitimde yenilik kapsamında değerlendirilmelidir. 21. yüzyılın yetkinliklerine göre yaratıcı fikir üreten, farkındalığı yüksek, özgüven sahibi, çevresiyle etkili iletişim kuran, takım çalışmasını benimsemiş, enformasyon teknolojilerini kullanma becerisine sahip, yabancı diller bilen öğretmen adaylarını yetiştirmekeğitimde yenilik kavramının lokomotifi niteliğinde olacaktır (Göl ve Bülbül, 2012). Bilgi çağında köklü bir değişime uğrayan iş piyasasının talepleri hızla değişmeye devam edecektir. Eğitim aktörlerinin sektörün ihtiyaç duyduğu iş gücünün yetkinliklerini öğrencilere kazandırabilmeleri için, ders tasarımlarını yalnızca öğreten değil bilginin inşasına öncülük eden şeklinde yapmaları gerekmektedir. Ders tasarımları yapılırken yeniliğe yüklenen anlam ülkelerin ihtiyaçlarına ve gelecekten beklentilerine göre şekillendirilmelidir (Kocasaraç ve Karataş, 2017). Eğitim örgütleri içerisinde örnek uygulamaların sergilenmesi, ödüllendirilmesi yeniliğin desteklenmesini ve yaygınlaşmasını sağlayacaktır. Eğitim ve iletişim, değişime direnmeyi engellemede kullanılan yöntemlerdendir. Örgütsel değişimin gerekliliğinin ve faydalarının toplantılar aracılığı ile tüm çalışanlara aktarılması, değişme giden yoldaki engelleri azaltabilir (Thampson ve Thampson, 1984: 394).

Şüphesiz ki okullarda gerçekleştirilecek bir yenileşme sürecinin en önemli aktörleri öğretmenlerdir. Okulların değişim ya da yenileşme sürecinde, öğretmenlerin fikirlerine başvurulması süreçleri daha uzun süreli, daha etkili ve sağlıklı yapacaktır (Beycioğlu ve Aslan, 2010, s.162). Fullan'a (1993, s.5) göre, öğretmenlerin işleri eskisinden daha karmaşık hale gelmiştir. Öğretmenler, değişen öğrenci ihtiyaçlarına, farklılaşan eğitim metod ve tekniklerine, sektörde hızla değişen teknolojiye ve toplumun farklı kesim- 
lerinden gelen isteklere cevap verebilecek nitelikte eğitim süreçlerini planlamalı ve uygulamalıdır. Öğretmenler, toplumsal ilerlemenin ve eğitimsel değişimin, değişim ve değişim sürecinin doğası hakkında bilinçli olması gerek aracilar olmalıdır (Fullan, 1993; Harris ve Muijs, 2005). Lieberman ve Mace (2008) öğretmen öğrenmesinin eğitim reformlarının kilidi olduğunu belirtir. Öğretmenin profesyonel gelişiminde asıl gereksinim öğretmenin uygulamaya dönük becerilerinin geliştirilmesidir. Çoğu zaman verilen eğitimlerin gerçek yaşamda olan bitenler ve sınıf uygulamaları ile ilişkisiz olduğu görülmektedir.

Buldu (2014) öğretmenlerin mesleki gelişim eğitimleri planlanması üzerine bir sistem önerisi sunduğu çalışmasında, Milli Eğitim Bakanlığı ve Eğitim Fakültelerinin gelişim sürecinde en önemli iki paydaş olduğunu belirtir. Ancak öğretmen sayısının çok olması, bu iki kurumun yeterli olmasını zorlaştırmaktadır. Bu nedenle bu çalışmada öğretmenlerin bireysel öğrenme çabalarına da yer verilmiştir.

Bümen ve arkadaşları (2012) mesleki gelişim modellerini inceledikleri çalışmalarında, öğretmen algısının ya da "öğretmen kimdir?" sorusuna verilen cevapların modellere yön verdiği bulgusuna ulaşmışlardır. Diğer bir deyişle, öğretmeni pasif bir uygulayıcı ya da teknisyen olarak gören paradigma, mesleki gelişim için kurs modelini uygun görürken; öğretmeni, deneyimlerinin mimarı ya da kendini geliştiren bir düşünür olarak gören paradigma, mesleki gelişim için çalışma grupları, eylem araştırması, akran koçluğu, rehberli bireysel gelişim modeli gibi uygulamaları dikkate almaktadır. İlgili araştırmanın sorularını şekillendiren rehberli bireysel gelişim modeli, kendi öğrenmelerini yönlendiren yetişkinlerin öğrenmeye istekli olacakları ve daha etkili öğrenecekleri görüşünü temel alır. Bu modelde öğrenmeyi öğretmeler kendileri tasarlar, gereksinim duydukları konularda öğrenme hedeflerini belirleyerek bu hedeflere yönelik öğrenme etkinliklerini (seminere, çalıştaya katılma vb.) seçerler ve kendi öğrenmelerini değerlendirirler (Guskey, 2000; Sparks ve Loucks-Horsley, 2007).

Hammerness ve arkadaşları (2005) öğretmen öğrenmesini iki boyutta incelerler. Verimlilik boyutunda, öğretmenin çok fazla kaynak olmaksızın görevlerini yerine getirmesi konusundaki yeterlilikleri yer alır. Yenilik boyutunda ise, yenilikçi öğretmen öğrenmesi, eski rutinlerin terk edilmesi ve önceki inançların değiştirilmesini amaçlanır. (Van Driel, Bulte ve Verloop, 2007). 
Son yıllarda bir dizi reform ve üniversite ortaklıkları ile yaratıcllığın ve öğretmenlerin birbirlerinden öğrenebilecekleri firsatların ön plana çıktığı öğrenme ortamları oluşmaya başlamıştır (Lieberman, 1992).

Bu gerekçeler ile bu araştırmanın amacı, yenilik ve değişim sürecine ilişkin öğretmen görüşlerini incelemektir. Her bir araştırma sorusu ise araştırmanın alt amaçlarını oluşturmaktadır. Bu bağlamda araştırmanın alt amaçları şunlardır:

1. Öğretmenlerin yenilik ve değişim kavramına bakış açılarını açıklamak,

2. Öğretmenlik mesleğini icra ederken gözlemledikleri değişimleri ve yenilikleri anlamak,

3. Öğretmenlerin yenilik ve değişim süreçlerindeki haber kaynaklarını öğrenmek,

4. Öğretmenlerin yenilik ve değişim sürecinde hissettikleri duyguyu öğrenmek,

5. Öğretmenlerin yenilik ve değişim sonrasında nasıl davrandıklarını açıklamak,

6. Öğretmenlerin bireysel değişim, yenilenme ve öğrenme çabanı hangi araç, yöntem ve tekniklerle desteklerini açıklamak,

7. Öğretmenlerin bireysel öğrenmelerini destekleyici önerilerini öğrenmek.

\section{Yöntem}

\section{Araştırma Modeli}

Bu araştırmada araştırma konusunun doğasına uygun olarak nitel araştırma yöntemlerinden olan Olgubilim/Fenomenoloji deseni kullanılmıştır. Olgubilim deseni, farkında olduğumuz ancak derinlemesine ve ayrıntılı bir anlayışa sahip olmak istediğimiz olgulara odaklanır. Olgular; yaşadığımız dünyada olaylar, deneyimler, algilar, yönelimler, kavramlar ve durumlar gibi çeşitli biçimlerde karşımıza çıabilmektedir. Olgularla günlük yaşamda sık sık karşılaşılmasına rağmen tam olarak anlaşılmayan durumların olduğunu söylemek mümkündür. İnsanlara tümüyle yabancı olmayan aynı zamanda da tam anlamının kavranamadığı olguları araştırmayı amaçlayan çalışmalar için, olgubilim deseni iyi bir araştırma yöntemi olmaktadır (Yıldırım ve Şimşek, 2008). 


\section{Çalışma Grubu}

Çalışma grubu büyüklüğü ile ilgili kesin bir sayı ölçütünün olmadığı nitel araştırmalarda (Hackett ve Schwarzenbach, 2016) çalışma grubu büyüklüğü yerine, çalışma grubunun araştırmacının gereksinim duyduğu bilgi miktarını karşılayıp karşılamadığı üzerinde durulmaktadır (Türnüklü, 2000). Ayrıca araştırmacıların, katılımcı sayısını belirlerken zaman, maliyet, kaynağa erişebilme durumlarını dikkate almaları da gerekmektedir (Hackett ve Schwarzenbach, 2016). Bu araştırmada söz konusu durumların yanı sıra farklı branşlarda ve cinsiyetlerde çalışmakta olan öğretmenlerinin çalışma grubundaki varlığı esas alınmıştır. Çalışma grubu, 2017-2018 EğitimÖğretim Yılı'nda devlet okullarında çalışmakta olan 5' i kadın ve 3'ü erkek olmak üzere 8 öğretmen oluşturmaktadır. Araştırma etiği çerçevesinde katılımcıların gönüllü olmasına özen gösterilmiştir. Bir diğer dikkat edilen etik ilke ise gizlilik ve anonimliktir. Gizlilik, araştırma katılımcısının kimliğini ortaya koyabilecek her türlü öğenin araştırma kayıtlarından çıkarılması girişimi iken; anonimlik, araştırmaya katılan kişilerin isimsiz kalmasıdır (Aydın, 2006). Katılımcıların özellikleri Tablo 1'de verilmektedir.

\section{Tablo 1. Katılımcılara ilişkin bilgiler}

\begin{tabular}{lllll}
\hline Katılımc1 & Cinsiyet & Yaş & Kıdem & Branş \\
\hline K1 & Kadın & 44 & 19 & Sını Öğretmeni \\
K2 & Kadın & 27 & 4 & Okul Öncesi Öğretmeni \\
K3 & Erkek & 30 & 6 & Sınıf Öğretmeni \\
K4 & Erkek & 37 & 14 & Sınıf Öğretmeni \\
K5 & Kadın & 53 & 19 & Ingilizce Öğretmeni \\
K6 & Kadın & 27 & 4 & Fen Bilgisi Öğretmeni \\
K7 & Erkek & 31 & 5 & Matematik Öğretmeni \\
K8 & Kadın & 36 & 15 & Rehber Öğretmen \\
\hline
\end{tabular}

Tablo 1'de görüldüğü üzere, katılımcı öğretmenlerin branşları, kıdemleri ve cinsiyetlerinin dağılımı araştırmanın inandırıcılığı açısından homojendir.

\section{Veri Toplama Araci}

Araştırma verilerinin toplanmasında, nitel araştırma tekniklerinden yarı yapılandırılmış görüşme tekniği kullanılmıştır. Yarı yapılandırılmış görüşmede araştırmacı, görüşme sorularını önceden hazırlar, kişilere sınırlı 
(kısmi) bir esneklik sağlayarak soruları görüşme sırasında yeniden düzenleyebilir, ihtiyaca göre yeni sorular ekleyebilir (Yıldırım ve Şimşek, 2008; Kılınç, 2007; Karasar, 2009).

Görüşme formunun hazırlanmasında ilgili alanyazından faydalanılmıştır. Amaca göre hazırlanan soruların anlaşılırlığı, çalışma grubu haricindeki öğretmenlere sorularak test edilmiştir. Bu esnada sorular amaca uygunluk, anlaşılırlık ve işlerlik boyutları ile değerlendirilmiştir. Soru formunun geçerlilik ve güvenirliği tekrarlı sorular sorma, ayrıntılı alıntılar yapma, ayrıntılı analiz, ayrıntılı betimleme ve katılımcı teyidi (geribildirim/dönüt) alma stratejileri ile arttırılmaya çalışılmıştır.

Veri toplama aracının hazırlanmasından, uygulama ve analiz aşamasına kadar araştırma süreci ayrıntılarıyla açıklanarak geçerlik ve güvenirlik artırılmaya çalışılmıştır. Yıldırım ve Şimşek (2008), veri toplama sürecinin ayrıntılı olarak açılanmasının ve araştırmacının araştırma verilerine nasıl ulaşıldığını detaylı olarak rapor etmesinin, nitel bir araştırmada geçerliğin önemli kıstalarından olduğunu belirtmişlerdir. Bu bağlamda veri toplama aracı araştırmacı tarafından geliştirilen ve 7 açık uçlu soruyu kapsayan bir yarı yapılandırılmış görüşme formundan oluşmuştur. Veri toplama arac1nın geliştirilme sürecinde hazırlanan sorular alanında uzman iki öğretim üyesine ve iki Türkçe öğretmenine incelemeleri için verilmiş, inceleme sonucunda soruların açık ve anlaşılır olduğu saptanmıştır. Ayrıca sorular örneklemde bulunmayan iki öğretmene cevaplandırılmıştır. Geri dönütlere dayanılarak soruların son şekli verilmiştir. Araştırmada katılımcılara yöneltilen sorular şunlardır:

1. Yenilik ve değişim deyince ne anlıyorsunuz?

2. Öğretmenlik mesleğini icra ederken neler değişiyor ve hangi yenilikler gerçekleşiyor?

3. Yenilik ve değişim süreçlerinden nasıl haberdar oluyorsunuz?

4. Yenilik ve değişimleri öğrenme sonrasında duygu ve davranışlarınızda hangi değişiklikler oluyor? (Ne düşünüyor, ne hissediyorsunuz?)

5. Yenilik ve değişim sürecinde meslektaşlarınız neler yapıyor?

6. Siz bireysel değişim, yenilenme ve öğrenme çabanızı hangi araç, yöntem ve tekniklerle destekliyorsunuz?

7. Neler olursa bireysel öğrenmeleriniz desteklenir? 


\section{Verilerin Toplanmast}

Görüşmeler 2018 Ocak ayı içerisinde yüz yüze gerçekleştirilmiştir. Gerçekleştirilen görüşmelerde öğretmenlerin gönüllülüğüne, pozitif bir görüşme ortamı yaratılmasına ve görüşme kayıtlarının gizliliğine vurgu yapılmıştır. Görüşmeler ses kayıt cihazı ile kayıt altına alınmış ve 183 dakika ses kaydı elde edilmiştir.

\section{Verilerin Analizi}

Nitel verilerin analize hazırlanmasında ilk olarak yanıtların tamamı metin halinde verilere dönüştürülmüştür. Araştırmacının verileri yakından tanıması ve veriye hâkim olması çok önemli olduğu için (Kabakçı ve Yurdakul, 2016) verilerin dökümü birebir araştırmacı tarafından yapılmıştır. Verilerin çözümlenmesinde ise içerik analizinden yararlanılmıştır. İçerik analizinde, temelde yapılan işlem, birbirine benzeyen verileri belirli kavramlar ve temalar çerçevesinde bir araya getirmek ve bunu okuyucunun anlayabileceği bir biçimde organize ederek yorumlamaktadır. İçerik analizinde temel amaç, toplanan verileri açıklayabilecek kavramlara ve ilişkilere ulaşmaktır. Bu yolla veriler tanımlanmaya, verilerin içinde saklı olabilecek gerçekler ortaya çıkarılmaya çalışılır (Yıldırım ve Şimşek, 2008). Temalar altında verilen yanıtların sıklık düzeyleri tespit edilmiş, bulgulara temel teşkil etmiştir. Temalar sınıflandırılırken temaların verilen tüm yanıtları içermesine özen gösterilmiştir. Yanitların yalnızca bir tema altında bulunmasına ve temaların birbirinden bağımsız olmasına dikkat edilmiştir. Bu doğrultuda veriler dört aşamada analiz edilmiştir: (1) verilerin kodlanması, (2) temaların bulunması, (3) kodların ve temaların düzenlenmesi, (4) bulguların tanımlanması ve yorumlanması (Yıldırım ve Şimşek, 2011).

\section{Nitel Araştırmada Geçerlik ve Güvenirlik}

Mills'e (2003) göre, geçerlik ve güvenirlik daha çok nicel araştırmalarda kullanılmakta olup nitel yaklaşımı açıklamakta yetersiz kalmaktadır. Bu yüzden araştırmada geçerlik ve güvenirlik kavramları yerine inandırıcılık, aktarılabilirlik, tutarlılık ve teyit edilebilirlik kavramları tercih edilmiştir. Bu bağlamda 
araştırmada Doğan, Uğurlu ve Karakaş'ın (2014) çalışmalarında takip ettikleri sürece benzer olarak: Araştırmada inandırıcilığı sağlamak için öncelikle araştırmanın uygulama sürecinde tüm görüşmeler ses kayıt cihazıyla ve not alınarak kayıt altına alınmıştır. Sonraki aşamada ise veriler Word programına aktarılmıştır. Araştırmacı, araştırmanın sürecinin bütününde objektifliğini korumaya özen göstermiştir. Aktarılabilirlik bağlamında araştırmacının okuyuculara, uygulama ve içerikteki benzerlikleri görebilmesi için yeterli detayları vermesi gerekmektedir. Bu nedenle çalışmanın yöntem bölümünde; araştırmanın yapıldığı zaman, içerik ve yer ile ilgili açıklayıcı bir şekilde okuyucu bilgilendirilmiştir. Araştırmanın tutarlılığını artırmak için çalışmada elde edilen bulguların tamamı yorum ve genelleme yapılmaksızın doğrudan okuyucuya sunulmuştur. Ayrıca araştırma sürecinde elde edilen tüm veriler, araştırmacının kendisi dışında, nitel araştırma sürecine hakim başka bir araştırmacı tarafından değerlendirip, ayrı ayrı kodlanmış ve tüm kodlamalar arasında genel anlamda görüş birliği sağlanmıştır. İki araştırmacının birbirinden bağımsız olarak kullandıkları kodların tutarlığı "Görüş Birliği” ya da "Görüş Ayrılığı" şeklinde işaretlemeler yapılarak belirlenmiştir. Buna göre nitel verileri inceleyen iki uzman arasında \%84 oranında görüş birliği sağlanmıştır. Araştırmanın teyit edilebilirliğini sağlamak için, verilerin elde edilme süreci detayları ile birlikte sunulmuştur.

\section{Bulgular}

Katılımcıların, görüşme formunda yer alan açık uçlu sorulara verdikleri yanıtlar soru bazında ayrı ayrı incelenmiş, her bir soru için öncelikle ana temalar ve bu ana temaları şekillendiren alt temalar belirlenmiştir.

1.soruda öğretmenlere, "değişim ve yenilik kavramlarını nasıl tanımladıkları" sorulmuştur. Öğretmenlerin verdiği yanıtlar, Tablo 2'de görüldüğü gibi 5 tema altında toplanmıştır. En fazla tekrar eden temaların "fayda sağlayan, amaca hizmet eden ve kullanılabilir olan" ve "normalden farklı, özgün yöntem ve teknikler" temaları olduğu görülmektedir. 
Tablo 2. Öğretmenlerin değişim ve yenilik kavramına ilişkin tanımları

\begin{tabular}{lr}
\hline Tema & $\mathbf{f}$ \\
\hline Tema-1: Fayda sağlayan, amaca hizmet eden ve kullanılabilir olan & 4 \\
Tema-2: Normalden farklı, özgün yöntem ve teknikler & 4 \\
Tema-3: Zamanla oluşan farklılıklar ve çağa ayak uydurma & 2 \\
Tema-4: Daha öncesinde var olmayan & 1 \\
Tema-5: Var olanın üstüne yapılan eklemeler & 1 \\
\hline
\end{tabular}

2.soruda öğretmenlere, "mesleklerini icra ederken nelerin değiştiği ve yenilendiğì" sorulmuştur. Katılımcların verdiği yanıtlar, Tablo 3'de görüldüğü gibi 4 tema altında toplanmıştır. En fazla tekrar eden temanın "eğitim sistemindeki genel değişimler" olduğu görülmektedir.

Tablo 3. Öğretmenlerin karşılaştıkları değişim ve yenilikler

\begin{tabular}{ll}
\hline Tema & $\mathbf{f}$ \\
\hline Tema-1: Eğitim sistemindeki genel değişimler & 8 \\
Tema-2: Eğitim öğretim metot ve tekniklerindeki yenilik ve değişimler & 6 \\
Tema-3: Teknolojideki değişim ve yenilikler & 6 \\
Tema-4: Toplumsal ve bireysel değişim ve yenilikler & 3 \\
\hline
\end{tabular}

Öğretmenlerin mesleklerini icra ederken karşılaştıkları değişim ve yeniliklere ilişkin betimleyici bazı ifadeler şunlardır:

- K3: "Eğitim sistemi siklıkla değişmesi (ki bunu tasvip etmiyoruz), sık sistem değişiklikleri yerine mevcut sisteme teknolojiyi uyarlayalım. Sik olan değişikliklere adapte olmak ve uygulamak zor oluyor. Kahcı sistemin üzerine fikir üretelim."(Tema-1)

- K7:"Dersin anlatış şekli ve örnekler değisşiyor, müfredatta her yıl değişiklikler oluyor, matematikte her yıl 1-2 konu değişiyor. Hala nasıl olması gerektiğini bilmediklerini ve bulmaya çalıştıklarını düşünüyorum. Ancak her yıl değişiklik olduğu için sonuç görülemiyor" (Tema-1).

- K8: "Sinav sistemi sürekli değişiyor" (Tema-1).

- K1:"Öğrenciler değişiyor, öğrencilerin bildikleri değişiyor, smıflar değişiyor, akıllı tahtalar var, kıyafetlerimiz değişsti, bunlar okulun kültür ortamın farklılaştırdı" (Tema-4).

- K4: Dünya değişiyor, çocuklar, sistem, teknoloji, araç gereçler, okul sisteminin de bunlara uyum sağlaması gerekiyor. Bilgiye ulaşım kolaylaştı, öğrenciler çeşitli 
alanlarda senden iyi olabiliyor. Bu da öğretmenin yenilenmesini şart klliyor. Artan uyarıclar ile daha kinestetik, yaparak-yaşayarak öğrenmeler destekleniyor (Tema-4).

3.soruda öğretmenlere, "yenilik ve değişim süreçlerinden nasıl haberdar oldukları" sorulmuştur. Katılımciların verdiği yanıtlar, Tablo 4'de görüldüğü gibi 4 tema altında toplanmıştır. En fazla tekrar eden temanın "yüz yüze iletişim ile meslektaşlardan" olduğu görülmektedir.

Tablo 4. Öğretmenlerin yenilik ve değişim süreçlerinden haberdar olma araçları

\begin{tabular}{lc}
\hline Tema & $\mathbf{f}$ \\
\hline Tema-1: Yüz yüze iletişim ile meslektaşlardan & 5 \\
Tema-2: İlgili web sayfalarından, eğitimle ilgili sitelerden & 4 \\
Tema-3: Sosyal medya araçlarından & 4 \\
Tema-4: Seminerlerden & 2 \\
\hline
\end{tabular}

Öğretmenlerin yenilik ve değişim süreçlerinden haberdar olma araçlarına ilişkin betimleyici bazı ifadeler şunlardır:

- K5: "Zaman içinde okulda haberim oluyor. Bizi sistemli bir eğitime alm-yorlar. Kendi kendimize öğrendik. Geç öğrendiğimiz için veli ve öğrencilere aktarmamız zor oldu sistemin oturması da gecikti. 4+4+4 de de aynisı oldu. Öncesinde verimli bir eğitime alınmamız gerekiyordu (Tema-1).

4.soruda öğretmenlere, "yenilik ve değişimleri öğrenme sonrasında duygu ve davranışlarındaki değişikler" sorulmuştur. Katılımcıların verdiği yanıtlar, Tablo 5'de görüldügüü gibi 2 tema altında toplanmıştır.

Tablo 5. Yenilik ve değişimlerin katılımcılar üzerindeki etkisi

\begin{tabular}{lr}
\hline Tema & $\mathbf{f}$ \\
\hline Tema-1: Direnç & 5 \\
Tema-2: Kabul ve uygulama & 3 \\
\hline
\end{tabular}

Yenilik ve değişimlerin öğretmenler üzerindeki etkisi ilişkin betimleyici bazı ifadeler şunlardır:

- K1: "Direnç gelişiyor, zamanla uyum sağlanıyor. Eğer o değişim işe yartyor ise daha kolay uyum sağlanıyor. Angaryadan ibaret ise kabul edilmiyor."(Tema-1) 
- K4:"Yenilikler alışkanlıklar bırakılmadığı için uygulanmıyor. Geleneksel yapı devam ediyor. Öğretmenlerin hırsları daha fazlasın yaptırıyor. Veli için yenilik gevşeklik demek. Veli çocuğun daha fazla soru çözmesini istiyor." (Tema-1)

- K7: "Yeni bir şey öğrendiğimde seviniyorum. Basit ve etkili olabiliyor, heyecan yaratıyor." (Tema-2).

- K8: "Öğrenince heyecanlanıyorum, ben ne yapabilirim diye düşünüyorum ve yeni olanı kendi çalışma alanlarım ile ilişkilendirerek eyleme geçiyorum." (Tema-2).

5.soruda öğretmenlere, "yenilik ve değişim sürecinde meslektaşlarının neler yaptığı" sorulmuştur. Katılımcıların verdiği yanıtlar, Tablo 6'da görüldüğ̈ü gibi 2 tema altında toplanmıştır.

Tablo 6. Yenilik ve değişim sürecinde öğretmen davranışları

\begin{tabular}{ll}
\hline Tema & $\mathbf{f}$ \\
\hline Tema-1: Eylemsizlik, eskisi gibi devam etme & 7 \\
Tema-2: Eyleme geçme & 5 \\
\hline
\end{tabular}

Yenilik ve değişim sürecinde öğretmen davranışlarına ilişkin betimleyici bazı ifadeler şunlardır:

- K1: "Bir kesim hiçbir şey yapmıyor. Klasik yöntemini devam ettiren ve öğretmen kılavuz kitapların açmayanlar çoğunluktadır. Yeni yöntem ve tekniklerden haberdar değiller"(Tema-1).

- K2: "Bir de kaygısı olmayan öğretmen grubu var fiziksel ve içsel denetleme olmadığı için klasik yöntemler ile öğrenciyi oyalarlar. Dışarıdan da böyle beklenti olmaz ise öğretmen düzenini bozmuyor." (Tema-1).

- K7: "Daha alışamadan yenisi geliyor, çok hılı değişiyor. 4 yılı bitiremeden yeni bir şey geliyor. Çok fazla bir şey yaptıkların düşünmüyorum." (Tema-1).

- K3: "Meslektaşlarımız kendi aralarında konuşuyor, dersi ve konuyu nasıl anlattığımızı birbirimize soruyoruz. Meslektaşlarm çoğu yeniliklerde heyecanlanyyor ve ilgileniyor." (Tema-2).

- K2: "Çalışan ve hırslı olan öğretmenler var. Yeniliği takip eder ve materyal kullanırlar. Teknolojiyi kullanırlar. Her konu ile ilgili görsel var, çocuklar için ilgi çekici ve hazır materyaller var. Yapılan uygulamaların yeniliklerin öğrencinin seviyesine uygun olması ve sinırlarımın çizilmesi gerekiyor." (Tema-2). 
Katılımcilara 6. soruda "bireysel değişim, yenilenme ve öğrenme çabalarını hangi araç, yöntem ve tekniklerle destekledikleri" sorulmuştur. Katılımcıların verdiği yanıtlar, Tablo 7'de görüldüğü gibi 9 tema altında toplanmıştır. En fazla tekrar eden temaların "web sayfaları ve sosyal medya araçları" ve "diğer paydaşlar (veliler, STK'lar, yerel yönetimler, okullar vb.)" temaları olduğu görülmektedir.

Tablo 7. Ö ̆̆retmenlerin bireysel öğrenme çabaların destekleyen araçlar

\begin{tabular}{ll}
\hline Tema & $\mathbf{f}$ \\
\hline Tema-1: Web sayfaları ve sosyal medya araçları & 8 \\
Tema-2: Diğer paydaşlar (veliler, STK'lar, yerel yönetimler, okullar vb.) & 8 \\
Tema-3: Meslektaş ögrenmesi & 7 \\
Tema-4: Kitaplar ve süreli yayınlar & 5 \\
Tema-5: Fuarlar, sempozyum ve kongreler & 3 \\
Tema-6: Kurslar ve etkinlikler & 3 \\
Tema-7: Resmi yazılar (genelgeler, tebliğler vb.) & 3 \\
Tema-8: Filmler & 2 \\
Tema-9: Hizmetiçi eğitimler & 2 \\
\hline
\end{tabular}

Öğretmenlerin bireysel öğrenme çabalarını destekleyen araçlara ilişkin betimleyici bazı ifadeler şunlardır:

- K6: "Sosyal medya araçlar ile ilgili fen bilimleri gruplarna ve genel öğretmen gruplarna üyeyim, yapılan işler paylaşılıyor, ben de kendi sınıfima uyarlyyorum, laboratuvar düzenlemelerimi yapıyorum ve kendi arkadaşlarımla da bunu paylaşıyorum".(Tema-1)

- K5: "Velilerden bilgi alı bilgi veriyorum, sivil toplum kuruluşlarn ile aktif çalışıyorum, yerel yönetimlerin projelerine dahil oluyorum, diğer okulları geziyorum." (Tema-2).

- K6: "Branş arkadaşlarn ile ortak kurduğumuz sitemiz var. İlk yıllarımda ders izleme yapmıştım." (Tema-3).

- K4: "Fuarlar, sempozyum ve kongrelere aktifkatıliyor, iyi uygulamalarn görüyor ve sunuyorum." (Tema-5).

- K1: "Kurslardan halk eğitimin tiyatro kursuna 1,5 yıl tiyatro, sinıf içi oyunlar, müzik, drama kursları sinıf içinde çok etkili oluyor." (Tema-6). 
- K4: "Hizmetiçi eğitimlerde uygulamal olanlarn verimli olduğunu düşünüyorum, ilkyardım ve yangın eğitimi gibi, bu etkinlikler artmalı ve uygulamalı olmalı, yangın tüpü ile söndürme çalışması gibi. Özellikle seminer dönemlerinde bu çalışmalar yapılmalı." (Tema-9).

Katılımcılara 7. soruda "bireysel çabalarını destekleyecek araçların iyileştirilmesine yönelik önerileri" sorulmuştur. Katılımcıların verdiği yanıtlar, Tablo 8'de görüldüğ̈̈ gibi 4 tema altında toplanmıştır. En fazla tekrar eden temaların "etkili hizmetiçi eğitimler" ve "yenilikleri destekleyecek genel sistem" temaları olduğu görülmektedir.

Tablo 8. Öğretmenlerin bireysel öğrenme çabaların destekleyen araçların geliştirilmesine yönelik önerileri

\begin{tabular}{lc}
\hline Tema & $\mathbf{f}$ \\
\hline Tema-1: Etkili hizmetiçi eğitimler & 5 \\
Tema-2: yenilikleri destekleyecek genel sistem & 5 \\
Tema-3: yenilikleri uygulayacak, öğrenmeye açı öğretmen & 4 \\
Tema-4: yenilikleri uygulayabilecek öğrenme ortamları & 3 \\
\hline
\end{tabular}

Öğretmenlerin bireysel öğrenme çabalarını destekleyen araçların iyileştirilmesine yönelik önerilerine ilişkin betimleyici bazı ifadeler şunlardir:

- K2: "Yetkin kişilerin verdiği hizmetiçi eğitimler olmalı ve küçük gruplara verilmeli."(Tema-1).

- K5: "Hizmetiçi eğitim veren kişiler tecrübelerini paylaşsın ve uygulama örnekleri versinler" (Tema-1).

- K2: "Milli eğitimin genel çerçevesinin yenilik ve yaratıcllğa izin verir nitelikte olması gerekir" (Tema-2).

- K3: "Sistem not alıp ya da verip geçme üzerine olduğu için öğrenme odaklı girmiyoruz. Özellikle üniversitelerde bu anlayışın verilmesi gerekiyor. Öğrencilerde sinava yönelik çalışıyor, öğretmen de" (Tema-2).

- K7: "Daha fazla okumamiz gerekir, algılarm açık olacak, izlediğin ve gördü̈̆̈̈̈n her şeyi mesleğin açısından harmanlayıp değerlendirmeli ve kullanmalısın." (Tema-3).

- K4: "Sınıf ortamlar dönüşümlü kullanılacak daha geniş alanlara çevrilebilmeli, alanlar öğrenmeleri yansitacak nitelikte olmalı" (Tema-4). 


\section{Tartışma}

Bu bölümde araştırma bulguları özetlenerek bundan önceki araştırma bulguları doğrultusunda tartışılacaktır. Öğretmenlerin yenilik ve değişim kavramına ilişkin betimlemelerine bakıldığında; "fayda sağlayan, amaca hizmet eden ve kullanılabilir olan", "normalden farklı, özgün yöntem ve teknikler" ile "zamanla oluşan farklılıklar ve çağa ayak uydurma" söylemlerinin ağırlık kazandığı görülmektedir. Kocasaraç ve Karataş (2017) öğretmenlerin yenilik kavramına ilişkin betimlemelerini öğrendikleri çalışmalarında, öğretmenlerin en çok "Teknoloji”, "Uyum sağlama", "Günceli takip", "Kendini geliştirme" temalarına vurgu yaptıklarını tespit etmişlerdir. Bu araştırmanın bulguları özellikle "uyum ve gelişme kavramları bağlamında Kocasaraç ve Karataş' ın (2017) bulguları ile uyumludur.

Öğretmenler, "mesleklerini icra ederken nelerin değiştiği ve yenilenenleri" sırası ile eğitim sistemindeki genel değişimler, eğitim öğretim metot ve tekniklerindeki yenilik ve değişimler, teknolojideki değişim ve yenilikler olarak belirtmişlerdir. Usluel ve Mazman (2010, s.60), eğitim alanında yapılmış çalışmalarda yenilikler arasında bilgi ve iletişim teknolojilerinin en fazla incelenen yenilik olduğunu belirlemişlerdir. Süreçte yer alan öğeler açısından yarar algısı, kullanım kolaylığı, sosyal etki ve kolaylaştırıcı faktörlerin en fazla vurgulanan öğeler olduğunu; yarar algısının yeniliği kullanım, yeniye karşı tutum ya da kullanım niyeti üzerinde en çok etkiye sahip olan öğe olduğunu bulmuşlardır. Ortamda yenilikle ilgili kolaylaştırıcı faktörlerin bulunması, yeniye ilişkin kullanım kolaylığı algısını ve yarar algısını arttırarak ve dolayısıyla kullanım ya da benimseme sürecini kolaylaştırmaktadır.

Öğretmenler yenilik ve değişim süreçlerinden, yüz yüze iletişim ile meslektaşlarından, ilgili web sayfalarından, eğitimle ilgili sitelerden ve sosyal medya araçlarından haberdar olmaktadır. Aydoğan (2007, s.13) çalışanların bireysel olarak değişime direnç göstermelerinin nedenleri arasında yeni durum hakkında yetersiz bilgiye sahip olmamalarını, değişimin yapacağı etkiyi ve değişim karşısında ne şekilde hareket etmeleri gerektiğini bilememelerini sıralar. "Değişim sonucunda mevcut konumumda kalabilecek miyim?" gibi kaygılar da değişime direncin en önemli sebepleri arasındadır.

Öğretmenlerin, "yenilik ve değişimleri öğrenme sonrasında duygu ve davranışları" ağırlıklı olarak "direnç" ardından ise "kabul ve uygulama" 
olmak üzere iki başlıkta toplanmıştır. King, Warren ve Peart (1988) yaptıkları çalışmada, öğretmenlerin en önemli on stres kaynağından biri olarak bakanlığın süreçleri yönlendirmesi ve müfredat ya da ders içeriği değişikliğini bulmuşlardır. Çok sayıda yeniliğin eğitim kurumlarının gündeminde olması ve yeniliklerin gerekli ön çalışmalar yapılmadan uygulamaya konması, çoğu kez başarısızlığı da beraberinde getirmektedir. Öğretmenlerin yeniliklerle ilgili olumsuz deneyimleri ise onların yeni programlara karşı tutumlarını doğrudan etkilemektedir (Karip, 1997). Değişim sadece rasyonel düşünme değil aynı zamanda duygusal ve motivasyonel yönleri de olan bir süreçtir (Hargreaves, 1998; Van Veen vd, 2005). Duygusal ve motivasyon boyutlara ilişkin bilinç öğretmen öğrenmesinin hızlanmasında ve eğitim reformlarının uygulanmasında kritik öneme sahiptir. Değişim güvensiz hissettirir ve hayal kırıklığına uğratabilir. Bu belirsizlik sürecinde güven ve destek veren bir süpervizyon süreci olumsuz duyguları daha kabul edilir hale getirir. (Hoekstra ve Korthagen,2011, s.89). Palmer (1998, s.10), iyi öğretimin sadece teknik ile sınırlandırılamayacağını; iyi öğretimin öğretmenin kimliği ve bütünlüğünden kaynaklandığını belirtir. Töre (2017, s.133) öğretmenlerin mesleki gelişimi için atölye çalışması modeline dayalı bir uygulama geliştirildiği ve değerlendirdiği çalışmasında, öğretmenlerin eğitim planlamasına yeterlilikleri ölçüsünde dâhil edildiği, uygulamalı içeriklerin yer aldığı çalışmaların çalışanlarca kabulünün ve anlaşılırlığının kolaylaştırdığını bulmuştur. Akpınar ve Aydın (2007) ise bu araştırmanın aksine ilk ve ortaokul öğretmenlerinin, eğitimde yaşanan değişimleri olumlu bulduklarını ve bu değişimlerin Türk Eğitim Sistemine yansıtılmasını benimsediklerini bulmuşlardır.

Öğretmenler, "yenilik ve değişim sürecinde meslektaşlarının neler yaptığı" sorusuna "eylemsizlik, eskisi gibi devam etme" ve "eyleme geçme" olmak üzere iki başlıkta yanıt vermişlerdir. Kocasaraç ve Karataş (2017) araştırmalarında öğretmenlere kendilerini yenilikçi öğretmen olarak değerlendirme durumları sorulmuşlardır. Öğretmenlerin çoğunluğunun "Evet" (f = 11) yanıtını verdiği görülmüştür. Evet, yanıtı veren öğretmenler en çok teknolojiye ( $\mathrm{f}=4$ ) vurgu yapmışlardır. 10 öğretmen kendilerini “Kısmen” yenilikçi öğretmen olarak görürken, 3 öğretmenin kendilerini yenilikçi öğretmen olarak görmedikleri bulunmuştur. Aydoğan (2007, s.13) ilköğretim okulu yönetici ve öğretmenlerinin değişim süreciyle ilgili görüşlerini ince- 
leyen çalışmasında, okul yöneticisi ve öğretmenlerin okullarını benimseyerek değişime hazır oldukların bulmuştur. Buna karşın, örgütsel anlamda öğretmenler, yöneticiler kadar olumlu görüş belirtmemişlerdir. Bu durumun yapılan değişimler konusunda öğretmenlerin yeterince bilgilendirilmediğiyle ilgili olduğu anlaşılmıştır. Araştırmada sonucunda bu durum, yöneticilerin hemen tüm maddelere öğretmenlere göre daha fazla katılmaları sonucu okullardaki değişimin formal olduğu veya uygulamaya yeterince geçmediği şeklinde yorumlanmıştır.

Öğretmenler bireysel değişim, yenilenme ve öğrenme çabalarını hangi araç, yöntem ve tekniklerle destekledikleri" sorusuna sırası ile web sayfaları ve sosyal medya araçları, diğer paydaşlar (veliler, STK'lar, yerel yönetimler, okullar vb.) meslektaş öğrenmesi, kitaplar ve süreli yayınlar, sempozyum ve kongreler ile kurslar ve etkinlikler olarak yanıt vermişlerdir. Kocasaraç ve Karataş (2017) öğretmenlerin bilgiye ulaşmalarının kolay olduğunu düşündüklerini en fazla web sayfalarını ve diğer internet araçlarını kullandıklarını bulmuşlardır. Meslektaşlarla iletişim de sıklıkla tekrar edilen boyutlar arasındadır. Trust (2014) makalesinde, öğretmen öğrenmesinde profesyonel öğrenme ağlarının öneminden bahseder. Profesyonel öğrenme ağları öğretmenleri tüm dünyadaki diğer öğretmenler ile bir araya getirerek destek, tavsiye, geri bildirim ve işbirliği firsatları yaratır. Profesyonel öğrenme ağları, ayrıca öğretmenlerin bilgi toplamalarına, en son gelişmelerden haberdar olmalarına, öğretim teknikleri ve eğitim alandaki değişiklikleri öğrenmelerine firsat verir. Profesyonel öğrenme ağlarını bilgi toplama kanalları ve sosyal medya bağlantıları olarak iki başlık altında inceleyebiliriz. Bloglar, YouTube, haberler, gazeteler ve web siteleri bilgi toplama kanalları arasında iken; twitter, facebook, ning, wikis, edmodo sosyal medya bağlantıları arasında sayılmaktadır.

Briscoe ve Peters (1997, s.51) öğretmenlerin üniversitedeki araştırmacılar ve çalışma arkadaşları ile işbirliğini içerisinde yaptıkları öğrenme uygulamalarının değişimi kolaylaştırdığını bulmuşlardır. Böylece araştırmacılar ve öğretmenler birbirine içerik ve pedagojik bilgi açısından öğrenme fırsatı sunmuş, birbirlerini teşvik etmiş, yeni fikirleri uygulamak ve bilimdeki bireysel değişim süreçlerini destekleyerek sürdürebilmişlerdir. Öğretmenler süreç içerisinde değişim zorluğunu hissetmiş; ancak, fikirleri, hayal kırıklıklarını ve sınırlılıklarını tartışabilecekleri ortamların kendileri için ödül- 
lendirici olduğunu belirtmişlerdir. Hoekstra ve Korthagen (2011) öğretmenlerin değişime yönelik onamlı (formal) ve onamsız (informal) öğrenmelerini inceledikleri boylamsal araştırmada, düzenli olarak verilen süpervizyonun öğretmenlerin inançlarında farkındalık yarattı̆̆ını öğrenme sürecinde yer alan kişisel faktörlerin ve bireysel çabaların başa çıkmada etkili olduğunu bulmuşlardır.

Kose ve Lim (2011, s.197), öğretmenlerin kendilerini geliştirmeleri bağlamında mesleki gelişim ve mesleki öğrenme olarak iki temel boyuttan söz eder. Mesleki gelişim, lisansüstü programlar, dışsal çalıştaylar, sempozyumlar gibi geleneksel yöntemleri kapsarken; meslektaş dayanışması, çalışma grupları, mesleki öğrenme, danışmanlık, planlama yapma, eş çalışanların gözetimi gibi okulla ilişkili öğrenme etkinliklerini içerir. İlgan (2013), etkili mesleki gelişim faaliyetlerinde işbirliğinin önemine değinir. Öğretmenlerin öğrenme topluluklarına katılarak aktif ve interaktif öğrenme deneyimlerini kendilerinin de yaşaması önemlidir. Konusunun okuma yazma öğretimi olan mesleki gelişim faaliyetini, meslektaşlarıyla süreğen bir şekilde tartışan öğretmenlerin öğrencilerinin okuma yazmada daha başarılı oldukları ortaya çıkmıştır. Mesleki öğrenme toplulukları, işbirlikçi bir bağlamda öğretmenin gelişmesi için katalizör konumundadır. İngiltere' de öğretmelerin mesleki gelişimlerini inceleyen bir çalışmada, öğretmenlerin mesleki gelişimlerini en fazla desteklediklerini düşündükleri çalışmalar sırası ile meslektaş gözlemi, uygulamaların paylaşımı, çevrimiçi kurslar, mentörlük ve sosyal ağlar olarak bulunmuştur (Boyle, While, ve Boyle, 2004).

Öğretmenlerin bireysel çabalarını destekleyecek araçların iyileştirilmesine yönelik önerileri incelendiğinde, sırası ile etkili hizmetiçi eğitimler, yenilikleri destekleyecek genel sistem, yenilikleri uygulayacak öğretmen ve yenilikleri uygulayabilecek öğrenme ortamları görülmektedir. Kocasaraç ve Karataş (2017), öğretmenlerin hizmetiçi eğitimlerin kalitesiz, sayısının yetersiz, seçiminin adaletsiz olduğuna vurgu yaptıklarını bulmuşlardır. Gelişime yönelik etkinlikler boyutunda, uluslararası projeler ve bilimsel çalışmaların etkisinin yüksek olduğunu bulmuşlardır. Öğretmenlere, kendi geliştirilebilir alanlarını fark etme olanağını vererek, öğretim yöntemlerini tüm yönleri ile analiz edebilme becerileri kazandırılmalıdır. Eğitim programı, sınıf yönetimi ve öğretim yaklaşımı öğrenci performansını en fazla 
etkileyen değişkenlerdir. Öğretmenlerin özellikle bu alanlarda yetiştirilmesi ve yenilikler ile tanıştırılması gerekmektedir. Okulda etkili eğitim ortamını destekleyici bir kurum iklimi yaratılmalıdır. Bu iklim, herkesten yüksek beklentiler içinde olmalı, öğretimi vurgulamalı, akademik ve işbirlikçi ilişkileri özendirmeli, ortaklaşa planlamayı, başarının tanınması ve ödüllendirilmesine önem vermeli, öğrencilerin etkili öğrenmesine yol açan bir disiplin ve düzeni işaret etmelidir.

Öğretmenler program, öğretim yöntemleri vb. konularda ihtiyaç duydukları değişiklikleri kendileri tespit edip, bu konularda kendi değişim taleplerini ve süreçlerini yönlendirebilmeli; okulda değişim kültürü oluşturmanın, değişim sürecinin ve farklılaşan öğrenmenin okul ortamında öğrencilerin başarısına olumlu etki yaptığını bilmelidir (Beycioğlu ve Aslan, 2010, s.162). Darling ve Richardson (2009) öğretmenlerin öğrencilere nasıl öğretecekleri bilgisinin verildiği spesifik, aktif, uygulamaya dönük, eğitim reformları ile ilişkili, işbirlikçi, yoğun ve sürdürülebilir eğitimlerin profesyonel gelişimi daha fazla desteklediği bulgusuna ulaşmışlardır

Jurasaite-Harbison ve Rex (2010) 3 farklı ülkede yapmış oldukları nitel çalışmada okul kültürünün öğretmenlerin informal öğrenmeleri üzerinde etkili olduğunu bulmuşlardır. Araştırma sonuçlarına göre öğretmenlerin informal öğrenmelerini destekleyen okulların özellikleri şunlardır:

1. Okulun fiziksel ve sosyal çevresi mesleki etkileşimi destekleyici niteliktedir.

2. İşbirliği öğretmenler ve yöneticiler arasında açık bir amaç ve süreçtir.

3. Öğretmenler ve idareciler eğitim politikaları konusunda ortak görüş benimserler.

4. Diş paydaşlar ile işbirliğine dönük firsatlar desteklenir.

5. Öğretmenler onamsız (informal) öğrenmeyi işlerinin önemli bir parçası olarak görür.

6. Kurumsal tarih ve ulusal politikalar istikrarlı ve olumlu bir çevre yaratır.

Yaylacı (2013, s.36), öğretmenlerin kendilerini geliştirmelerine ilişkin uygulamalar bağlamında diğer bir önemli konunun ise, eğitim merkezleri olduğunu belirtir. Eğitim bakanlığının tek merkez olarak düzenlediği ve kontrol ettiği bir sistemin aksine, birçok kaynaktan eğitim ve geliştirme etkinliklerinin alınabilmesini önerir. Altun ve Vural (2012) yapmış oldukları 
çalışmada, öğretmenlerin büyük çoğunluğu merkezi ve yerel otoriteler tarafından kendilerine sunulan mesleki gelişim fırsatlarını yetersiz bulduklarını tespit etmişlerdir. Ayrıca, okul gelişimin temelinde öğretmen gelişiminin yattığı, öğretmenlerin bireysel olarak okul gelişimine katkıda bulunabileceği sonuçlarına ulaşılmışlardır.

Meirink ve arkadaşları (2010), öğretmen takımları arasındaki iş ilişkilerinde karşılıklı bağımlılığın öğretmen öğrenmesinde kilit rol oynadığını tespit etmişlerdir. İşbirliği ve öğrenme birbirine bağlıdır. Bireysel öğretmen öğrenmesi, pedagojik inançlardaki ve sınıflardaki değişiklikleri kapsayan uygulamaların yanı sıra, iş arkadaşlarıyla işbirliği içinde çalışma ilişkilerini de beraberinde getirir. Parise ve Spillane (2010), onamlı (formal) mesleki gelişim ve işbaşındaki öğrenme fırsatlarının öğretmenlerin ders içerisinde yaptıkları uygulamalardaki değişiklikler ile ilişkili olduğunu bulmuşlardır. Araştırmacılar formal mesleki gelişim fırsatlarını konuya özel oturumlar, okul dışı öğretmenler ile kurulan ağlar olarak betimlerken; işbaşındaki öğrenme fırsatlarını etrafındaki meslektaşlarla etkileşime geçerek öğretme ve öğrenme, karşılıklı tartışmalar, çalışma arkadaşlarını gözlemleme, geribildirim alma ve talimatlarla ilgili danışma önerileri alma olarak açıklamışlardır. Ayrıca öğretmenlerin kendi aralarında yaptıkları işbirliğine dayalı tartışmalar, öğretmenlerin sınıf içi uygulamalarda değişikliğe girmelerinin etkili yordayıcısı olarak bulunmuştur.

Kelly (2006) öğretmen öğrenmesini etkileyen faktörleri incelediği çalışmasında, okullardaki öğrenme ikliminin önemine değinir. Öğretmen ile öğrencilerinin öğrenme çıtılarının ilişkili olması ve fiziksel kaynaklara ulaşılabilirlik, öğrenmeyi destekleyici etmenler arasında yer almaktadır. Araştırmacılar (Şahin ve Arcagök, 2014; Yaman ve Yazar, 2015) öğretmenlerin yaşam boyu öğrenme yeterliklerinin yüksek düzeyde olduğunu bulmuşlardır. Yaşam boyu öğrenme eğilimi en yüksek olan grup 6-11 yıl arasındaki kıdeme sahip öğretmenler iken, 21 ve üzeri yıl kıdeme sahip öğretmenlerin yaşam boyu öğrenme eğilimi en düşüktür (Yaman ve Yazar, 2015).

\section{Sonuç ve Öneriler}

Araştırma sonucunda öğretmenlerin "fayda sağlayan, amaca hizmet eden ve kullanılabilir olan" yeniliklere değer verdiklerini belirtmiş; "teknoloji”, 
"uyum sağlama", "günceli takip", "kendini geliştirme" temalarını vurgulamışlardır. Yenilik ve değişim süreçlerinden, yüz yüze iletişim ile meslektaşlarından, ilgili web sayfalarından, eğitimle ilgili sitelerden ve sosyal medya araçlarından haberdar oldukları ve yine bu yollarla bireysel öğrenmelerini destekledikleri belirtmişlerdir. Öğretmenlerin bireysel çabalarını destekleyecek araçların iyileştirilmesine yönelik önerileri incelendiğinde; sırası ile etkili hizmetiçi eğitimler, yenilikleri destekleyecek genel sistem, yenilikleri uygulayacak öğretmen ve yenilikleri uygulayabilecek öğrenme ortamları görülmektedir.

Araştırma bulgularından yola çıkarak uygulayıcılara ve karar vericilere aşağıdaki öneriler sunulmaktadır:

1. Değişiklikler yapılırken fayda sağlayan, amaca hizmet eden, kullanılabilir olan, normalden farkll, özgün süreçleri içermesi öğretmenlerce bu değişikliklerin yenilik olarak kabul edilmesini sağlayacaktır.

2. Genel sistem üzerinde yapılacak değişikliklerin iyi tasarlandıktan sonra yapılması, sürekli bir yeniliğe gidilmemesi önerilmektedir.

3. Ders içeriklerinde yapılan değişikliklerin zamana yayılması, bir değişiklik içselleştirilmeden diğerine geçilmemesi gerekmektedir.

4. Özellikle genel sistem değişiklilerinde, değişiklik öncesi öğretmenlerin konu hakkında bilgilendirilmesi gerekmektedir. Bu hem uygulamayı kolaylaştıracak, hem de öğretmenlerin değişime olan direncini azaltacaktır.

5. Yenilik sürecine uyum sağlayamayan öğretmenler başta olmak üzere tüm öğretmenlerin, bu süreçte desteklenmesi ve denetlenmesi yeni sürecin etkili yönetilmesi için önemlidir.

6. Ekip içerisindeki yeniliğe açı öğretmenlerin tespit edilerek, süreci hızlandırabilmeleri için onlara lokomotif görevi verilmesi önerilmektedir.

7. Branş bazındaki öğrenmeler başta olmak üzere, ilgili web sayfalarının kullanımı tüm öğretmenler için kolaylaştırıcı olacaktır.

8. Öğretmenlerin halk eğitim merkezleri ya da sivil toplum kuruluşları gibi birimlerden eğitimler almaları desteklenmektedir. Bu eğitim ağlarının oluşması için okullarda etkin iletişim ağları önerilmektedir. 
9. İlkyardım, yangın eğitimi, yeni öğretim metotlarının kullanımı gibi uygulamalı hizmetiçi eğitimlerin tasarlanması, daha küçük gruplarda verilmesi ve bu eğitimlere katılıcıların belirlenmesinde adil olunması önerilmektedir.

10. Okullarda sistemli meslektaş öğrenmesi ve paylaşım çalışmalarının yapılması önerilmektedir.

Nitel araştırma yöntemi kullanılan bu çalışma nicel araştırma yöntemleri ile desteklenebilir. Ayrıca bu araştırmanın çalışma grubu ilk ve ortaokul öğretmenlerinden oluşmuştur. Lise öğretmenleri ile okul yöneticilerinin de yenilik ve değişim sürecine ilişkin algılarının incelenmesinin faydalı olacağı düşünülmektedir. 


\title{
EXTENDED ABSTRACT
}

\section{Investigation of Teacher Views on Change and Innovation Process: A Qualitative Study}

\author{
Esra Töre \\ İstanbul Sabahattin Zaim University
}

Education is one of the most important elements of all societies. Increasingly, international discourse focuses on the relationship between the quality of teacher work on school development and educational reforms (Frost, 2012). Improving the quality of education is possible with qualified teachers. The rapidly changing and developing conditions in the twenty-first century, as well as the qualified training of teachers in faculties of education; In the process, they also required them to develop their experience, knowledge and skills (Gökulu, 2017).

Especially in our age, as the level of knowledge and skills required by technological changes increases, it becomes difficult to limit education to certain periods and programs that are traditional (Can, 2004, p.104). It is necessary for the individual to spend his / her life in the educational process in order to adapt himself / herself to these changes and adapt to changing or renewed educational conditions (Artan, 1995).

Dewey says, "As movement is a physical reality, change is a social reality (Beycioğlu, Aslan, 2010, p.153). Change in the educational process involves restructuring teachers' basic beliefs and ideas about learning materials and methods. (Fullan, 1991). When the literature is examined, it is seen that the concepts of change and innovation are used together by many researchers. According to Altrichter (2000, p.2) change or innovation describes a process of progress and its outcomes. According to Özdemir (2000, p.31), innovation is a pre-planned change that is planned to bring positive results under control. Innovation is change.

Innovation is the transformation of new ideas into products, processes, services and business practices and their successful use (Banburry and Mitchgell, 1995, p.163). According to Musluoğlu (2008), innovation in education means creating a higher quality education, raising children who 
catch up to date and think creatively, and make the education process more effective and target-oriented.

Undoubtedly, the most important actors in an innovation initiative in schools are teachers. Applying the opinions of teachers in an attempt to change or renew at school will make this initiative longer and healthier (Beycioğlu and Aslan, 2010, p.162). According to Fullan (1993, p.5), teachers' work has become more complex than before. Teachers must respond to the needs of the changing student universe, to rapidly changing technology at work, and to demands from different segments of society. Teachers are mediators, which means being conscious about the nature of social progress and educational change, the process of change and change (Fullan, 1993; Harris and Muijs, 2005). Lieberman and Mace (2008) state that teacher learning is the key to educational reforms.

\section{Aim of the Study}

The aim of this study is to examine the views of teachers in the process of innovation and change. Each research question constitutes the sub-objectives of the research. In this context, the sub-objectives of the research are as follows:

1. Explain teachers' perspective on innovation and change,

2. To understand the changes and innovations observed in the practice of teaching,

3. To learn the news sources of teachers in the process of innovation and change,

4. To learn the feelings that teachers felt during the process of innovation and change,

5. To explain how teachers behave after innovation and change,

6. Explain which tools, methods and techniques support teachers' individual change, renewal and learning effort,

7. To learn teachers' suggestions to support individual learning.

\section{Material and Method}

The research was structured according to the qualitative design and the data were collected through a semi-structured interview form developed by 
the researcher. The study group consists of eight teachers from six different branches working in primary and secondary schools. Seven semi-structured questions were asked face to face. The interviews were conducted in January 2018. During the interviews, volunteerism of teachers, creating a positive interview environment and confidentiality of interview records were emphasized. The interviews were recorded with a voice recorder and 183 minutes voice recording was obtained. The data obtained from the interviews were analyzed by content analysis method and themes and subthemes were obtained.

\section{Findings and Conclusions}

As a result of the research, it was found that teachers value innovations that "benefit, serve to goal and useful"; they stated themes are "technology", "adaptation", "current follow-up", "self-development ". The teachers stated that they are aware of innovation and change processes, face-to-face communication with their colleagues, related web pages, educational sites and social media tools and they support individual learning in these ways. Teachers cite the tools to support individual learning efforts as effective inservice trainings, general system to support innovations, teachers to implement innovations and learning environments to implement innovations. Based on the research findings it is suggested that informing teachers about changes and innovations; all teachers, especially those who cannot adapt to the innovation process, should be supported and supervised in this process. Increasing practical in-service trainings such as first aid training, fire training, and the use of new teaching methods, systematic peer learning and sharing activities in schools will support the process of change and innovation.

\section{Kaynakça / References}

Abrami, P. C., Poulsen, C. ve Chambers, B. (2004). Teacher motivation to implement an educational innovation: Factors differentiating users and nonusers of cooperative learning. Educational Psychology, 24(2), 201-216.

Akpinar, B., ve Aydin, K. (2007). Change in education and teachers' perceptions of change. Egitim ve Bilim, 32(144), 71-80. 
Altrichter, H (2000). “Introduction". Images of Educational Change. (Eds:Altrichter, H. ve Elliot, J.).Buckingham: Open University Press.

Altun, T., ve Vural, S. (2012). Bilim ve Sanat Merkezinde (BİLSEM) görev yapan öğretmen ve yöneticilerin mesleki gelişim ve okul gelişimine yönelik görüşlerinin değerlendirilmesi. Elektronik Sosyal Bilimler Dergisi, 11(42), 152-177.

Artan, S. (1995). Endüstri işletmelerinde yöneticilerin yetiştirilmesi ve Türkiye'de uygulama. Eskişehir: İTİA Yayınları No:172/107.

Aydın, İ. (2006). Sosyal bilimlerde araştırmadan yayına etik değerler. Sosyal Bilimlerde Süreli Yayıncılık, I. Ulusal Kurultay Bildirileri.

Aydoğan, İ. (2007). Değişimin süreci ve okul personeli. GAU J. Soc. E Appl. Sci, 3(5), 13-24.

Ali B. (1993). Etkili okul; Kuram, uygulama ve araştırma. Ankara: Yavuz Dağıtım 1993 , s. 43.

Banbury, C. M., ve Mitchell, W. (1995). The effect of introducing important incremental innovations on market share and business survival. Strategic Management Journal, 16(S1), 161-182.

Başaran, İ.E. (1998). Yönetimde insan ilişkileri. Ankara: Aydan Yayınevi.

Beycioğlu, K., ve Aslan, M. (2010). Okul Gelişiminde Temel Dinamik Olarak Değişim ve Yenileşme: Okul Yöneticileri ve Öğretmenlerin Rolleri (ss. 153173). Yüzüncü Yıl Üniversitesi Eğitim Fakültesi Dergisi, 7(1), 153-173.

Boyle, B., While, D. ve Boyle, T. (2004). A longitudinal study of teacher change: What makes professional development effective?. Curriculum Journal, 15(1), 45-68.

Briscoe, C., ve Peters, J. (1997). Teacher collaboration across and within schools: Supporting individual change in elementary science teaching. Science education, 81(1), 51-65.

Buldu, M. (2014). Öğretmen yeterlik düzeyi değerlendirmesi ve mesleki gelişim eğitimleri planlanması üzerine bir öneri. Milli Eğitim Dergisi, 44(204), 114-134.

Bümen, N. T., Ateş, A., Çakar, E., Ural, G. ve Acar, V. (2012). Türkiye bağlaminda öğretmenlerin mesleki gelişimi: sorunlar ve öneriler. Milli Ĕğitim Dergisi, 42(194), 31-50.

Can, N. (2004). Öğretmenlerin geliştirilmesi ve etkili öğretmen davranışları. Erciyes Üniversitesi Sosyal Bilimler Enstitüsü Dergisi, 16(1), 103-119.

Darling-Hammond, L. ve Richardson, N. (2009). Research review/teacher learning: What matters. Educational leadership, 66(5), 46-53. 
Doğan, S., Uğurlu, C. T. ve Karakaş, H. (2014) Etkili sınıf yönetimi uygulamalarına ilişkin öğretmen görüşlerinin değerlendirilmesi. Gaziantep University Journal of Social Sciences, 13(4), 1097-1119.

Erdoğan, İ. (2002). Ĕ̆itimde değişim yönetimi. Ankara: Pegem A Yayıncllık.

Frost, D. (2012). From professional development to system change: teacher leadership and innovation. Professional development in education, 38(2), 205-227.

Fullan, M. (1991). The NEW meaning of educational change 2nd ed.). New York: Teachers College Press.

Fullan, M. (1993). Change forces: Probing the depths of educational reform. London: The Falmer Press.

Genç, S. Z. (2000). Bilgi toplumunda öğretmen eğitimi. Kuram ve Uygulamada Ĕ̆itim Yönetimi, 6(3), 375-386.

Gökulu, A. (2017). Aday öğretmenlerin Türkiye'deki aday öğretmenlik eğitim süreci ile ilgili görüşleri. International Journal of Social Sciences and Education Research, 3(1), 111-123.

Göl, E., ve Bülbül, T. (2012). İlköğretim okulu yöneticilerinin yenilik yönetimi yeterliklerine ilişkin öğretmen algıları. Mersin Üniversitesi Eğitim Fakültesi Dergisi, 8(2), 97-109.

Guskey, T. R. (2000). Evaluating professional development. California: Corwin Press.

Hackett, P. M. W. ve Schwarzenbach, B. (2016). Ethnographic cavcats. In P. M. W. Hackett (Ed.), Qualitative research methods in consumer psychology: Ethnography and culture (pp. 53-66). New York, NY, London: Routledge.

Hammerness, K., Darling-Hammond, L., Bransford, J., Berliner, D., CochranSmith, M., McDonald, M., ve Zeichner, K. (2005). How teachers learn and develop. In L. Darling- Hammond \& J. Bransford (Eds.), Preparing teachers for a changing world (pp. 358-389). San Francisco, CA: Jossey-Bass.

Hargreaves, A. (1998). The emotions of teaching and educational change. In A. Hargreaves, A. Lieberman, M. Fullan, \&D. Hopkins (Eds.), International handbook of educational change (pp. 558-575). Dordrecht, Netherlands: luwer.

Harris, A. ve Muijs, D. (2005). Improving schools through teacher leadership. Berkshire: Open University Press. 
Hoekstra, A. ve Korthagen, F. (2011). Teacher learning in a context of educational change: Informal learning versus systematically supported learning. Journal of Teacher Education, 62(1), 76-92.

İlğan, A. (2013). Öğretmenler için etkili mesleki gelişim faaliyetleri. Uşak Üniversitesi Sosyal Bilimler Dergisi Özel Sayı, 41-56

Jurasaite-Harbison, E., ve Rex, L. A. (2010). School cultures as contexts for informal teacher learning. Teaching and teacher education, 26(2), 267-277.

Kabakçı Yurdakul, I. (2016). Nitel veri analizinin temelleri. Işıl Kabakçı Yurdakul Editör, Nitel veri analizinde adım adım NVivo kullanımı (s.1-21). Ankara: Anı Yayıncılık.

Karasar, N. (2009) Bilimsel araştırma yöntemi. Ankara: Nobel Yayın.

Karip, E. (1997). Eğitimde yeniliklerin uygulanmasını etkileyen etkenler. $K u$ ram ve Uygulamada Ĕ̆itim Yönetimi, 9(9), 63-82.

Kelly, P. (2006). What is teacher learning? A socio-cultural perspective. Oxford review of education, 32(4), 505-519.

Kılınç, U. K. (2007). Sosyal bilimler alanında gömülü teori yaklaşımı. İçinde Yüksel, A., Mil., B. ve Bilim, Y., Nitel Araştırma: Neden, Niçin, Nasıl, Detay Yayın, Ankara, 122-131.

King, A. J., Warren, W. K., ve Peart, M. J. (1988). The Teaching Experience: A Profile of Ontario Secondary School Teachers. Research Committee, Ontario Secondary School Teachers' Federation.

Kocasaraç, H. ve Karataş, H. (2017). Fen ve sosyal bilimler liselerinde görev yapan öğretmenlerin yenilikçi öğretmen özelliklerine yönelik algıları: bir durum çalışması. Journal of International Social Research, 10(52), 783-794.

Kose, B.W.; Lim, E. Y. (2011). Transformative professional learning within schools: relationship to teachers' beliefs, expertise and teaching. The Urban Review, 43(2), 196-216

Köhler, T., Janßen, C., Plath, S. C., Reese, J. P., Lay, J., Steinhausen, S., ... ve Pfaff, H. "Communication, Social Capital and Workplace Health Management as Determinants of The Innovative Climate in German Banks". International Journal of Public Health, 55(6), 2010, 561-570.

Lieberman, A. (1992). School-university partnerships: A view from the inside. Kappan, 74(2), 147-156.

Lieberman, A. ve Pointer Mace, D. H. (2008). Teacher learning: The key to educational reform. Journal of teacher education, 59(3), 226-234. 
Meirink, J. A., Imants, J., Meijer, P. C. ve Verloop, N. (2010). Teacher learning and collaboration in innovative teams. Cambridge journal of education, 40(2), 161-181.

Mills, G. E. (2003). Action research a guide for the teacher researcher (2 nd. edition). Boston:Pearson Education.

Özdemir, S. (2000). Eğitimde örgütsel yenileşme. (5.Baskı) Ankara: Pegem Yayıncilik

Özkalp, E. ve Kırel, Ç. (1996). Örgütsel davranış. Eskişehir: Anadolu Üniversitesi Yayın.

Palmer, P. J. (1998). The courage to teach. San Francisco, CA: Jossey-Bass.

Parise, L. M., ve Spillane, J. P. (2010). Teacher learning and instructional change: How formal and on-the-job learning opportunities predict change in elementary school teachers' practice. The elementary school journal, 110(3), 323-346.

Schumpeter, J. A. (1934). The theory of economic development: An inquiry into profits, capital, credit, interest, and the business cycle" (Vol. 55). Transaction Publishers.

Seferoğlu, S. S.(2004) Öğretmen yeterlilikleri ve mesleki gelişim. Bilim ve Aklın Aydınlığında Ĕ̆itim Dergisi, 58, 40-45.

Sparks, Dennis ve Loucks-Horsley, Susan (2007). Five models of staff development for teachers. İçinde: Ornstetin, A.C., Pajak, E.J. ve Ornstein, S.B. Contemporary issues in curriculum. 303-326. USA: Pearson.

Şahin, Ç. ve Arcagök, S. (2014). Öğretmenlerin yaşam boyu öğrenme yeterlikleri düzeyinin çeşitli değiş̧kenler açısından incelenmesi. Sosyal Bilimler Dergisi, 7(16), 394-417.

Thampson JB Thampson P. (1984). Organization and people. West Publising Company, Minesota.

Tobin, K., Briscoe, C., ve Holman, J. (1991). Overcoming constraints to effective elementary science teaching. Science Education, 74, 409-442.

Töre, E. (2017). Öğretmenlerin mesleki gelişimi için atölye çalışması modeline dayalı bir uygulamanın geliştirilmesi ve değerlendirilmesi. Marmara Üniversitesi Atatürk Ĕ̆itim Fakültesi Ĕ̆itim Bilimleri Dergisi, 46(46), 133-150.

Trust, T. (2012). Professional learning networks designed for teacher learning. Journal of Digital Learning in Teacher Education, 28(4), 133-138.

Turcsányi-Szabó, M. (2012). Aiming at sustainable innovation in teacher education-from theory to practice. Informatics in Education-An International Journal, 11(1), 115-130. 
Türnüklü, A. (2000). Eğitimbilim araştırmalarında etkin olarak kullanılabilecek nitel bir araştırma tekniği: Görüşme. Kuram ve Uygulamada Eğitim Yönetimi Dergisi, 6(4), 543-559.

Usluel, Y. K., ve Mazman, S. G. (2010). Eğitimde yeniliklerin yayılımı, kabulü ve benimsenmesi sürecinde yer alan öğeler: Bir içerik analizi çalışmas1. Cukurova University Faculty of Education Journal, 39, 60-74.

Van Driel, J.H., Bulte, A.M.W., \& Verloop, N. (2007). The relationships between teachers'general beliefs about teaching and learning and their domain specific curricular beliefs. Learning and Instruction, 17, 156-171.

Van Veen, K., Sleegers, P., ve Van de Ven, P. (2005). One teacher's identity, emotions, and commitment to change: A case study into the cognitive-affective processes of a secondary school teacher in the context of reforms. Teaching and Teacher Education, 21, 917-934.

Yaman, F., ve Yazar, T. (2015). Öğretmenlerin yaşam boyu öğrenme eğilimlerinin incelenmesi (Diyarbakır ili örneği). Kastamonu Eğitim Dergisi, 23(4), 1553-1566.

Yaylacı, A. F. (2013). Öğretmenlerin kendilerini geliştirmelerine ilişkin yaklaşım sorunu. Uşak Üniversitesi Sosyal Bilimler Dergisi, Özel Sayı, 25-40

Yıldırım A. ve Şimşek H. (2008). Sosyal Bilimlerde Nitel Araştırma Yöntemleri (7. Baskı) Ankara: Seçkin Yayıncılık.

\section{Kaynakça Bilgisi / Citation Information}

Töre, E. (2020). Değişim ve yenilik sürecine ilişkin öğretmen görüşlerinin incelenmesi: Nitel bir çalışma OPUS-Uluslararası Toplum Araştırmaları Dergisi, 15(22), 895-926. DOI: 10.26466/opus.644725 